\title{
Ecological distribution of four co-occurring Mediterranean heath species
}

\author{
Fernando Ojeda, Juan Arroyo and Teodoro Marañón
}

Ojeda, F., Arroyo, J. and Marañón, T. 2000. Ecological distribution of four co-occurring Mediterranean heath species. - Ecography 23: 148-159.

\begin{abstract}
Erica australis, E. scoparia, E. arborea and Calluna vulgaris are the most abundant heath species on acid, sandstone-derived soils of the Strait of Gibraltar region (southern Spain and northern Morocco). Despite their apparently similar ecological requirements, these four species are somewhat ecologically segregated. Erica australis is abundant only on poor, shallow soils, with a high content in soluble aluminium, generally on mountain ridges and summits. Erica scoparia becomes dominant on deeper sandstone soils with lower aluminium. Calluna vulgaris coexists with these Erica species in communities under low or no tree cover. In the Spanish side of the Strait (Algeciras), Erica arborea tends to be relegated to communities under moderate to dense tree cover, whereas this species is more abundant and widespread in the Moroccan side (Tangier). Tolerance to extreme physical conditions - high aluminium and dense tree cover - and interspecific competition seem to explain the ecological distribution of these four heath species in the Strait of Gibraltar region. The more fragmented pattern of sandstone patches and higher disturbance levels in Tangier might account for the differences in the patterns of ecological distribution of these four heath species between both sides of the Strait of Gibraltar.
\end{abstract}

F.Ojeda (ojeda@cica.es) and J. Arroyo, Dept de Biología Vegetal y Ecología, Univ.de Sevilla. Apdo 1095, E-41080 Sevilla, Spain. - T. Marañón, IRNA, CSIC, Apdo 1052, E-41080 Sevilla, Spain.

Variation in abundance of a plant species along an ecological gradient is the result of its physiological tolerance to adverse situations (e.g. resource limitations, toxicity), its interaction with other species (e.g. competition, herbivory, facilitation), and its response to disturbance (e.g. fire, flooding). This variation determines the species' response to that gradient (Austin 1985).

In a taxonomic context, heaths constitute a natural group of species - the subfamily Ericoideae - within the Ericaceae (Oliver 1989). They present a quite homogeneous habit (small-mid size shrubs with narrow, 'ericoid' leaves) which contrasts with a strongly diversified floral morphology (Rebelo et al. 1985, Arroyo and Herrera 1988). Heaths are mainly found on acid, nutrient-poor soils (Groves 1981, Oliver 1991, Ojeda et al. 1998), thriving in those environments thanks to their association with mycorrhizae (Pearson and Read 1973, Lamont 1982). About $95 \%$ of heath species (21 genera and ca 800 species) are native to southern Africa, most of them confined to the Cape floristic region (Oliver 1989). The subfamily Ericoideae is represented in the northern hemisphere by 20 species within three genera (Erica, Calluna and Bruckenthalia), mainly restricted to Europe and the north of Africa (Ojeda et al. 1998).

Heaths in the northern hemisphere have traditionally been associated with temperate latitudes owing to the abundance of heath-dominated plant communities (i.e. heathlands) in oceanic areas of western and northwestern Europe (Gimingham 1972, Gimingham et al. 1979). Nevertheless, most northern hemisphere heath

Accepted 7 June 1999

Copyright (C) ECOGRAPHY 2000

ISSN 0906-7590

Printed in Ireland - all rights reserved 
species are Mediterranean in origin (Greuter et al. 1986, Ojeda et al. 1998), despite heathlands being uncommon within the Mediterranean region. The Strait of Gibraltar region, at the western end of the Mediterranean Basin, harbours eight heath species (seven Erica species plus Calluna vulgaris (L.) Hull, cf. Valdés et al. 1987 and Jahandiez and Maire 1931-34), representing an important centre of diversity for the northern hemisphere (Ojeda et al. 1998). In this region, heathland is also a dominant vegetation-type and the most representative heath species are Erica australis L., E. scoparia L., E. arborea L. and Calluna vulgaris (see below). These four heath species, plus $E$. umbellata L. and $E$. multiflora L. (the latter only present at the Moroccan side of the Strait, Ojeda et al. 1996a), thrive in Mediterranean heathlands and shrublands (Ojeda 1995). However, two other heath species also present in the study area, E. erigena R. Ross and E. ciliaris L., do not seem to tolerate summer drought, characteristic of the Mediterranean climate, being restricted to permanently wet habitats, such as springs and river banks (de Benito 1948, Ojeda 1995)

In previous studies at the community level, we found that soil soluble aluminium and shade conditions were main factors determining the abundance patterns of woody species (Ojeda et al. 1995, 1996a) in woody communities of the Strait of Gibraltar region. In this paper we describe the ecological separation between Erica australis, E. scoparia, E. arborea and Calluna vulgaris along two main environmental gradients, the one related to soil aluminium, and the other related to overstorey tree cover, as a surrogate for the limitation by light deficit in shade conditions, at both sides of the Strait of Gibraltar. The toxicity caused by high soluble aluminium limits the growth of many plants in acid soils (Woolhouse 1981), thus justifying having selected the content of soluble aluminium in soil for the first environmental gradient. We vindicate the selection of the second environmental gradient, related to light availability, upon the fact of most heath species being light-demanding, growing in exposed sites (de Benito 1948, Gimingham 1960, Oliver 1989, 1991, Iason and Hester 1993).

Additionally, as a first account of the competitive ability of these plants, we have studied their performance, in terms of biomass allocation and reproductive efficiency, in contrasted sites of the two environmental gradients mentioned above.

The main aim of this paper is to determine whether patterns of ecological separation of these four heath species along the two environmental gradients considered are analogous at both sides of the Strait, given the close proximity and biogeographical similarities between the two peninsulas forming the Strait of Gibraltar (see below).

\section{Methods}

\section{Study area and species}

The Strait of Gibraltar region is formed by the confrontation of two small peninsulas, Algeciras at the north Spanish - side, and Tangier at the south - Moroccan - side, separating the Atlantic Ocean from the Mediterranean Sea (Fig. 1). Both peninsulas, barely separated $14 \mathrm{~km}$, have a ragged topography. Aljibe $(1092 \mathrm{~m})$ and Bou Hachem $(1681 \mathrm{~m})$ are the highest peaks in Algeciras and Tangier respectively. These peninsulas show remarkable floristic, biogeographical and ecological affinities (Valdés 1991, Ojeda et al. 1996a, Marañón et al. 1999). They are characterized by a mild Mediterranean climate (Table 1) due to oceanic influences, and by the dominant presence of acid, nutrient-poor, siliceous sandstone-derived soils (Ibarra 1993, Ojeda 1995) otherwise scarce in the Mediterranean Basin (Specht and Moll 1983). These soils also have a high exchangeable aluminium content (INIA 1970). They occur on sandstone mountains and hills, in the form of 'edaphic islands' surrounded by more fertile, marly or loamy lowlands (Ojeda et al. 1996a). The overall range of the area covered by these acid soils is smaller and more fragmented in Tangier (Fig. 1, Ojeda et al. 1996a).

Heathlands are dominant on acid soils, whereas more fertile, surrounding soils harbour 'maquis' or 'garriga' shrublands (Arroyo and Marañón 1990), a typical vegetation extending throughout the Mediterranean Basin, which is recognized as the paradigmatic type of Mediterranean vegetation (e.g. Tomaselli 1981). Heath species dominate open heathlands on poorly developed soils of exposed ridges and crests. They are also abundant on deeper soils of middle slopes, in the understorey of evergreen Quercus suber (cork oak) woodlands and semideciduous Quercus canariensis forests.

Slashing, grazing and fire constitute the main agents of disturbance on these heathlands. In Algeciras, heath communities under Quercus suber woodlands are slashed back every seventh to ninth year to facilitate cork harvesting. In Tangier, cork is less intensively exploited, but the rural population is much denser (El Hattab 1989, Deil 1990, 1993) and slashing for fencing and fuel is more severe (Ojeda 1995, Marañón et al. 1999). Grazing by goats and sheep is also more severe in Tangier than in Algeciras (El Hattab 1989, Marañón et al. 1999). Uncontrolled fires are frequent during the summers in both peninsulas.

Erica australis, E. scoparia, E. arborea and Calluna vulgaris are the most frequent heath species in these Mediterranean heathlands (Ojeda et al. 1996a). The habit of these three Erica species is rather similar, all being multistemmed and having a thick underground lignotuber (Rodríguez et al. 1994), out of which they readily resprout and regenerate their above-ground biomass after slashing or burning (Ojeda et al. 1996b, 


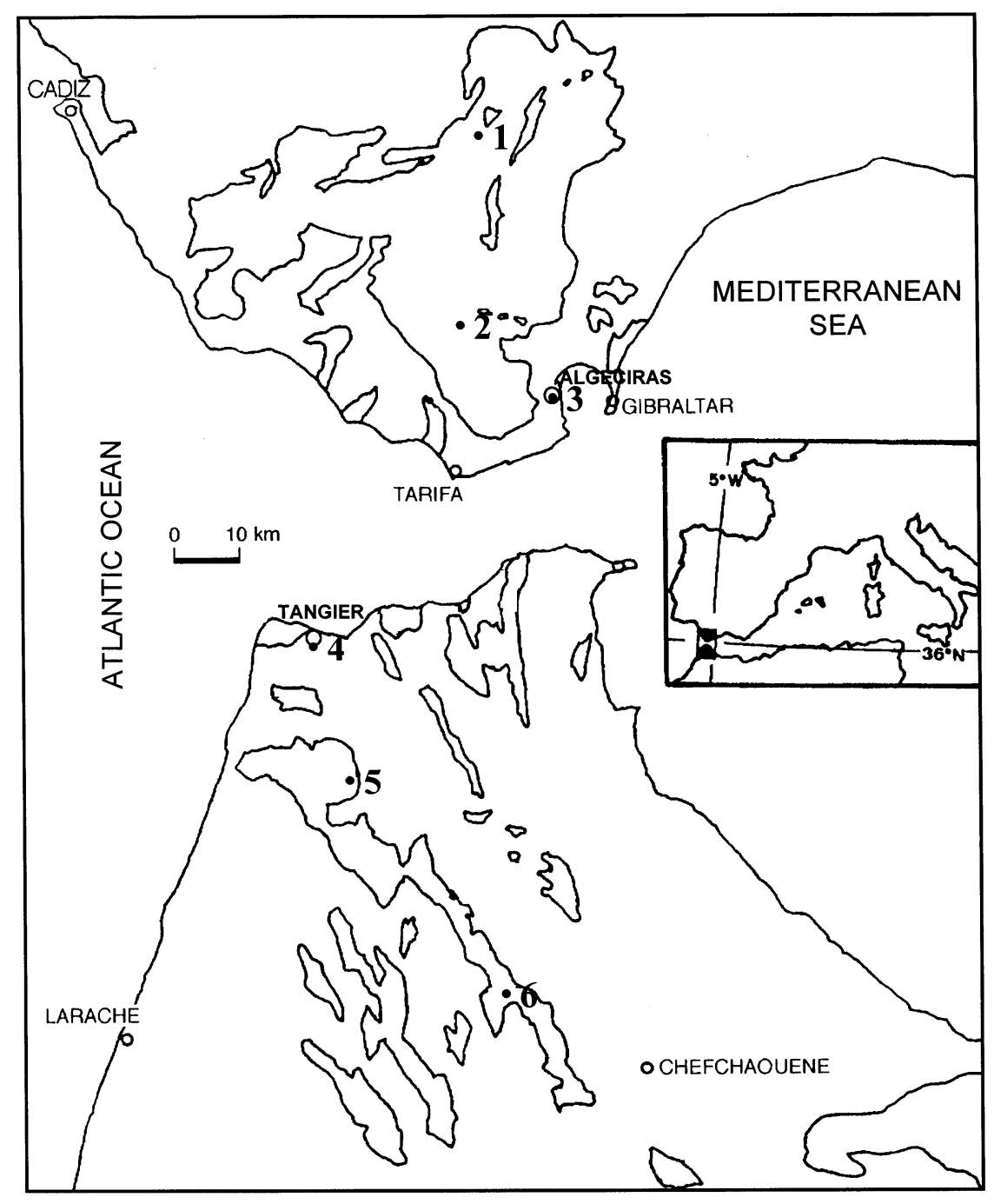

Fig. 1. Geographic location of the study area. Solid lines correspond roughly to patches of sandstone derived soils (see Ojeda et al. 1996a). Numbers indicate location of weather stations referred in Table 1.

Salvador et al. 1996). In contrast, Calluna lacks a lignotuber and the ability to resprout (but see Hobbs et al. 1984), although its post-disturbance seedling recruitment enables it to colonize burnt areas readily (Ojeda et al. 1996b). These four heath species thrive on acid and nutrient-poor soils and sunny exposures in the western
Mediterranean (Aubert 1977, 1978, Iason and Hester 1993, Rodríguez et al. 1994). However, despite their apparently similar ecological requirements, they are somewhat spatially segregated in the landscape of the Strait of Gibraltar region (Rodríguez et al. 1994, Ojeda 1998).

Table 1. Climatic data of six sites across the Strait of Gibraltar (see Fig. 1 for location of sites). M, mean of maximum temperatures within the hottest month; $\mathrm{m}$, mean of minimum temperatures within the coldest month; $\mathrm{T}$, mean annual temperature; $\mathrm{P}$, mean annual rainfall.

\begin{tabular}{lclcr}
\hline & $\mathrm{M}\left({ }^{\circ} \mathrm{C}\right)$ & $\mathrm{m}\left({ }^{\circ} \mathrm{C}\right)$ & $\mathrm{T}\left({ }^{\circ} \mathrm{C}\right)$ & $\mathrm{P}(\mathrm{mm})$ \\
\hline 1. San José del Valle(1) & 33.2 & 6.2 & 17.7 & 867 \\
2. Murta & - & 8.2 & - & 1429 \\
3. Algeciras & 27 & 9.6 & 17.2 & 778 \\
4. Tangier & 26.8 & 6.1 & 17.4 & 887 \\
5. Dar-Chaoui & 32.0 & - & - & 2168 \\
6. Jbel Bouhachem & $(4)$ & - & &
\end{tabular}

Data obtained from ${ }^{(1)}$ CEBAC-CSIC 1963, ${ }^{(2)}$ CSDIC 1983, ${ }^{(3)}$ Sauvage 1961, and ${ }^{(4)}$ Benabid 1982. 


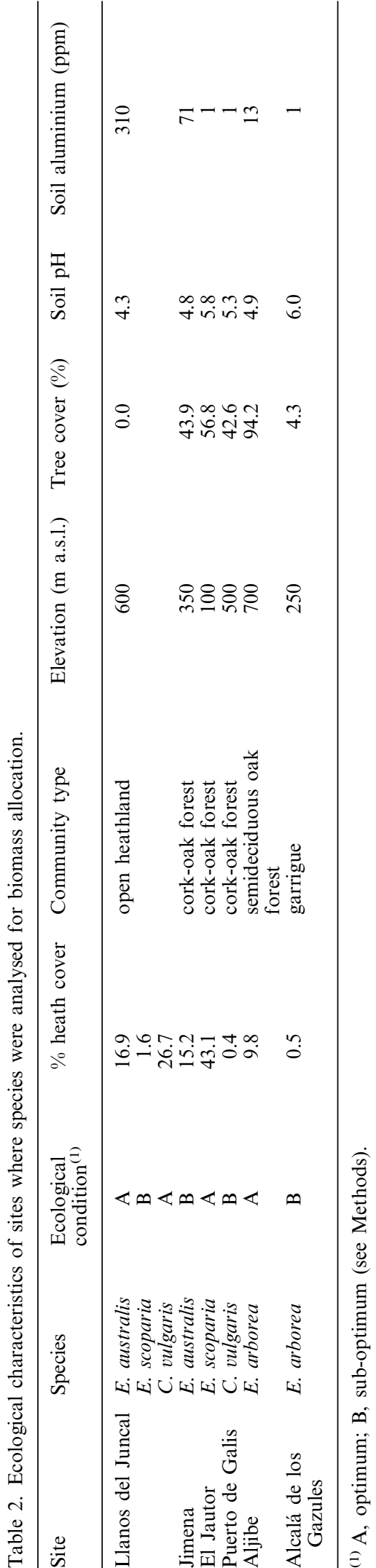

\section{Species abundance and environmental gradients}

The abundance of the four heath species was recorded in 63 sampling sites representing the main vegetation types in the region (31 sites in Algeciras and 32 in Tangier, see Ojeda et al. 1996a for location). Each species' abundance was estimated by measuring its relative cover in a $100 \mathrm{~m}$-line transect. Overstorey tree cover was recorded at each site on the same $100 \mathrm{~m}$. A soil sample (mixing 3 subsamples of about $20 \mathrm{~cm}$ diameter and $25 \mathrm{~cm}$ depth collected haphazardly along the $100 \mathrm{~m}$-line) was also taken and analysed for soluble aluminium (using methods described in Allen 1989).

Aluminium content in soil ranged from 1 to 486 parts per million in Algeciras samples and from 2 to 120 in Tangier. Overstorey tree cover ranged from nil to $100 \%$ in both geographical subsets of samples. Values of soil aluminium and tree cover of all samples were ranked and divided into thirds by two quantile cut-offs so as to have three levels of each environmental gradient for both subsets of samples.

\section{Species performance}

The performance of the species was estimated using several vegetative and reproductive parameters of plants sampled in contrasted habitats chosen among the study sites in Algeciras region. Ideally, we looked for two sites representing extremes of both environmental gradients and containing populations of the four heath species. After a careful examination of the community samples, and despite strong overlap of heath species, this complete co-occurrence requirement was impossible to achieve. Therefore, two samples having contrasted situations of both environmental gradients were selected for E. australis, E. scoparia and C. vulgaris, one of them being associated with high cover values of the species (i.e. its supposed 'optimum'). In the case of $E$. arborea, this scheme of 'optimum' vs 'sub-optimum' was mainly related to overstorey tree cover (Table 2). This part of the study was limited to Algeciras.

In each population three undamaged plants were selected, representing the average size in the population. Plants were dug out at their flowering peak, their branches were fragmented, kept in plastic bags and brought to the laboratory. Then, they were oven-dried at $60^{\circ} \mathrm{C}$ until constant weight (ca five days) and their woody parts (lignotuber when present, thick roots, stems) were hand-separated. The non-woody parts (leaves, flowers and fruits) are very small in all heath species and hence specific methods were designed for their separation.

In E. australis and C. vulgaris the total amount of leaves plus flowers was hand-separated from branches after drying. Then it was passed through a linear sieve (1.5 $\mathrm{mm}$ space between threads) which allowed the 
separation of leaves from flowers (size up to $8.5 \mathrm{~mm}$ in E. australis and $4.5 \mathrm{~mm}$ in C. vulgaris). Calluna vulgaris presented a partial methodological problem, due to the imbricate, non-linear leaves of their younger twigs which are not deciduous after drying. Hence, two samples ( $2 \mathrm{~g}$ each) for each plant were taken from the amount of unseparated leaves and young twigs. Leaves and twigs were then carefully separated and weighed, and then extrapolated to the fraction of unseparated material. The obtained values were added to those obtained by hand-separation (older leaves and branches).

For E. scoparia the sieve method was impossible to use, owing to the very small size of its flowers (Arroyo and Herrera 1988). Instead, total amount of leaves plus flowers of each plant was weighed and homogenised by stirring. Ten samples of the homogenate ( $1 \mathrm{~g}$ each) were obtained, the flowers and leaves were carefully hand-separated, weighed, and the values extrapolated to the whole plant.

In all species analysed, numbers of flowers were obtained indirectly, due to the very high number present in each plant (up to tens of thousands). The average dry weight of a flower of each species was estimated by weighing 50 flowers separately, and hence extrapolating to the weight of the whole flower biomass of each plant.

The vegetative performance of the plants through their potential photosynthetic efficiency was estimated as the relative foliar allocation, that is, the ratio leaves/ stems measured as dry weight. Reproductive performance was measured as relative flower allocation: the ratio total flower dry weight/above-ground vegetative matter (sum of dry weight of leaves and stems).

Due to the destructive nature of the methods above described, another measure of the reproductive performance of the plants (fruit set) was obtained from other plants in the populations. During the fruiting season, 10 branches (one per plant) were randomly selected in each population. On each branch, the number of flowers which set fruit was recorded over a sample of 300 flowers and given as a percentage. This was possible to be done in a single counting since flowers are persistent during most of fruiting season in heath species.

\section{Numerical analysis}

Despite range of the aluminium gradient being different between both geographical subsets of samples (see above), having ranked and divided both environmental gradients into three levels by means of two quantile cut-offs provided three matched levels of each environmental gradient in Algeciras and Tangier, which enabled us to make within-species comparisons between both peninsulas along the two environmental gradients by means of two-way ANOVAs. Previously, variable species' relative cover was arcsine transformed.

Ecological similarity or overlap between all pairs of heath species was quantitatively estimated through Schoener's (1970) method, which is based on the relative frequencies of each species in a pair along the communities. In this study, values of species relative cover (cover along the $100 \mathrm{~m}$-line transect) in each community were used.

Differences in biomass allocation between populations within each species were analysed using nonparametric Mann-Whitney tests (Sokal and Rohlf 1995), given the small sample size $(n=3)$ per population for the four species. Differences between populations in the percentage of fruit set $(n=10$ branches per population) were analysed by means of $t$ tests on arcsine transformed data. The Statistica software package (Anon. 1997) was used for all the statistical analyses.

\section{Results}

\section{Species response}

Erica australis and C. vulgaris are associated with soils with medium to high content of soluble aluminium (Fig. 2). This pattern is clearest in Algeciras, but it is maintained also in Tangier (Table 3).

Erica scoparia is abundant in Algeciras and, despite its lack of association with the soil aluminium gradient (Table 3), is the dominant heath species under relatively favourable edaphic conditions (i.e. soils with low soluble aluminium, Fig. 2). This species is significantly less abundant in Tangier (Table 3).

Erica arborea has a low abundance in Algeciras and has no significant response to the soil aluminium gradient (Fig. 2, Table 3). The presence of this species in Algeciras is only relevant in areas of high tree cover (Fig. 3). The other three heath species, in contrast, show no clear trends along this shade gradient (Table 3 ), although E. australis and $C$. vulgaris tend to be less abundant under medium-high tree cover (Fig. 3). Erica arborea is significantly more abundant in Tangier (Table 3), virtually embracing both soil aluminium and shade gradients (Figs 2 and 3). The ecological response of $E$. arborea along the tree cover (shade) gradient is different between peninsulas, as denoted by the significant interaction between region and gradient level effects (Table 3). In Tangier, this species is dominant under either low and high tree cover (Fig. 3).

Comparing the heath species responses between Algeciras and Tangier regions two main aspects emerge: 1) the overwhelming presence of E. arborea in Tangier throughout both soil aluminium and shade gradients, and 2) the seeming lesser presence of E. scoparia in Tangier compared with Algeciras. 


\section{Ecological overlap}

The values of ecological overlap, as indicated by the relative cover of the species in the community samples, are included in Table 4. Two facts are most remarkable: 1) the constant lower overlap between E. arborea and any other heath species in Algeciras in comparison with Tangier, and 2) the strong overlap between $C$. vulgaris and both $E$. australis and E. scoparia, especially in Algeciras.

\section{Species performance}

At the species level, E. arborea has the highest aboveground biomass (mean $=2.5 \mathrm{~kg}$ dry mass) and also the more massive lignotuber (mean $=2.6 \mathrm{~kg}$ ), followed closely by E. australis, with $2.1 \mathrm{~kg}$ of shoot dry mass and $2.3 \mathrm{~kg}$ of lignotuber. Erica scoparia plants are much smaller, with means of $0.6 \mathrm{~kg}$ above- and $1.6 \mathrm{~kg}$ below-ground, but still with a remarkable lignotuber. Calluna is a relatively small heath, it has a mean of 0.3 $\mathrm{kg}$ above-ground (9 times lower than E. arborea) and no specialised root morphology to resist disturbance, weighing only $0.1 \mathrm{~kg}$ of woody roots (Table 5). Relative foliar and flower allocation also seem to be to some extent genus specific and hence $C$. vulgaris presents up to about twice and three times the values of the Erica species studied (Fig. 4).

At the population level, both vegetative and reproductive parameters showed differences for the species studied in contrasted habitats (Fig. 4). Moreover, the species behaved in a different manner according to whether the population is close or far from its supposed ecological optimum (cf. Figs 2 and 3 for Algeciras).

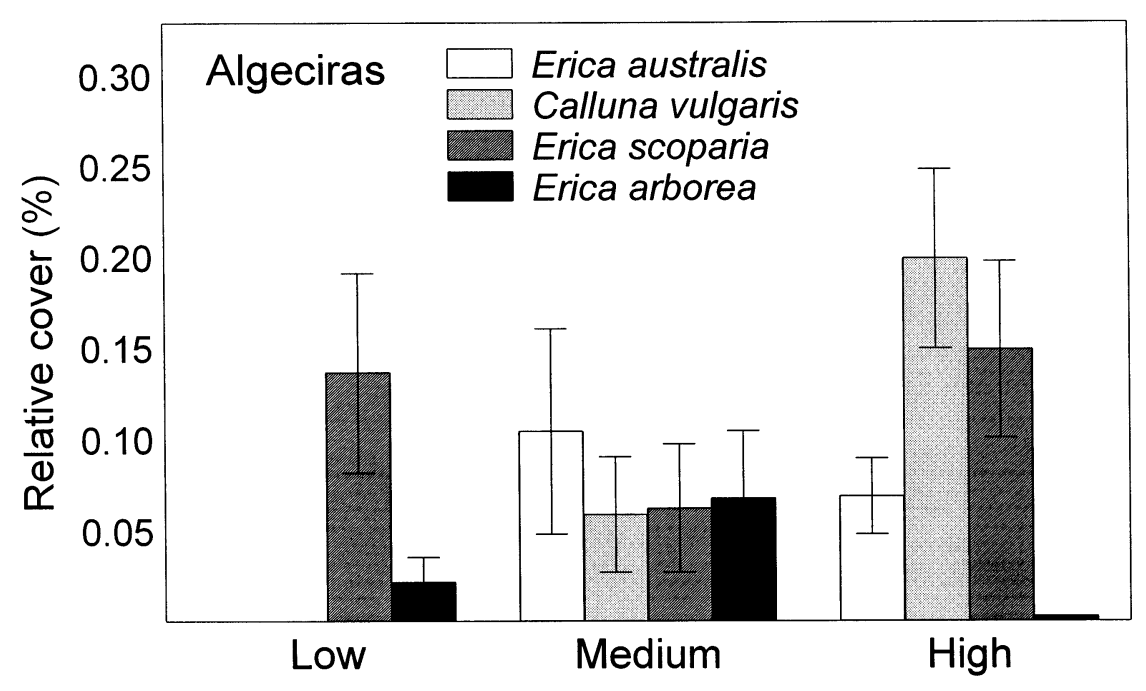

Fig. 2. Abundance of the four heath species in three situations on the edaphic (soil soluble aluminium) gradient.

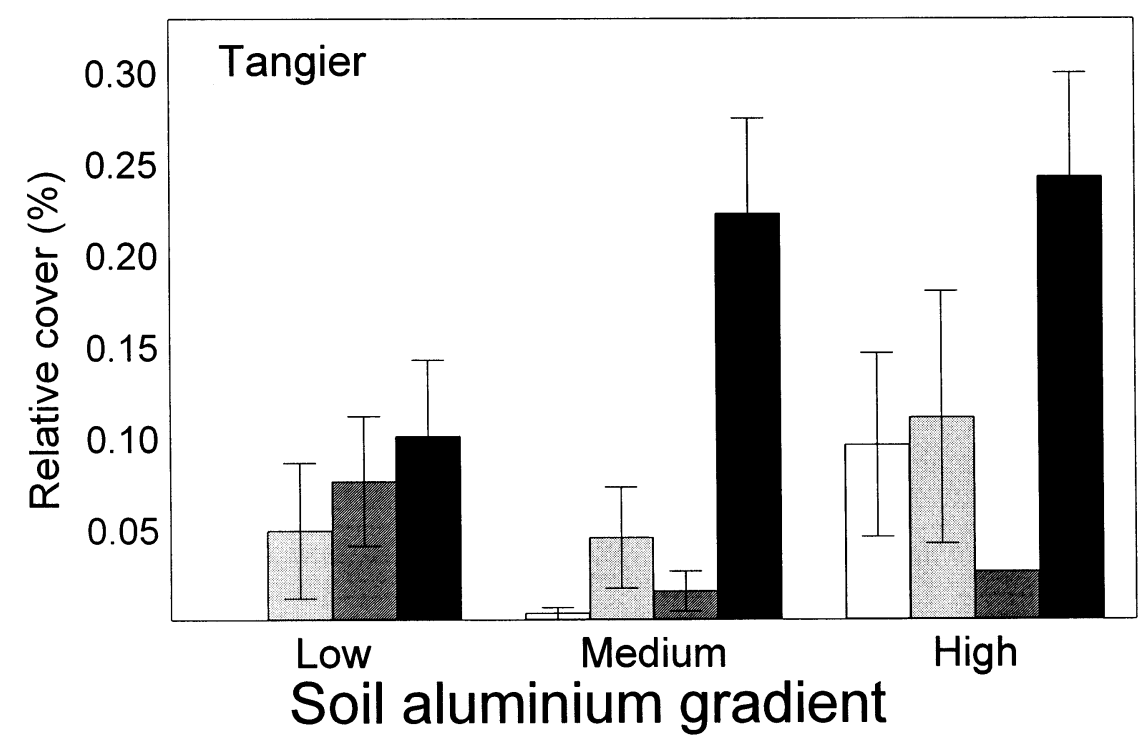

ECOGRAPHY 23:1 (2000) 
Table 3. Two-way ANOVA results for the comparison of the abundance (relative cover, arcsin-transformed data) of each heath species between regions (Algeciras and Tangier) at the three levels of each environmental gradient. Type III sums of squares are used throughout. Significance at $\mathrm{p}<0.05$.

\begin{tabular}{|c|c|c|c|c|c|c|}
\hline & \multicolumn{3}{|c|}{ Edaphic gradient (soil soluble aluminium) } & \multicolumn{3}{|c|}{ Shade gradient (tree cover) } \\
\hline & $\mathrm{DF}$ & MS & $\mathrm{F}$ & $\mathrm{DF}$ & MS & $\mathrm{F}$ \\
\hline \multicolumn{7}{|l|}{ E. australis } \\
\hline Region (R) & 1 & 0.054 & $1.56 \mathrm{~ns}$ & 1 & 0.060 & $1.58 \mathrm{~ns}$ \\
\hline Gradient level (L) & 2 & 0.222 & $6.43^{* *}$ & 2 & 0.087 & $2.29 \mathrm{~ns}$ \\
\hline Interaction $(\mathrm{R} \times \mathrm{L})$ & 2 & 0.051 & $1.47 \mathrm{~ns}$ & 2 & 0.086 & $2.27 \mathrm{~ns}$ \\
\hline Error & 57 & 0.034 & & 57 & 0.038 & \\
\hline \multicolumn{7}{|l|}{ C. vulgaris } \\
\hline $\mathrm{R}$ & 1 & 0.042 & $0.81 \mathrm{~ns}$ & 1 & 0.064 & $1.05 \mathrm{~ns}$ \\
\hline $\mathrm{L}$ & 2 & 0.303 & $5.75^{* *}$ & 2 & 0.181 & $2.99 \mathrm{~ns}$ \\
\hline $\mathrm{R} \times \mathrm{L}$ & 2 & 0.144 & $2.75 \mathrm{~ns}$ & 2 & 0.041 & $0.68 \mathrm{~ns}$ \\
\hline Error & 57 & 0.053 & & 57 & 0.060 & \\
\hline \multicolumn{7}{|l|}{ E. scoparia } \\
\hline $\mathrm{R}$ & 1 & 0.399 & $8.24 * *$ & 1 & 0.437 & $8.48^{* *}$ \\
\hline $\mathrm{L}$ & 2 & 0.081 & $1.67 \mathrm{~ns}$ & 2 & 0.051 & $0.98 \mathrm{~ns}$ \\
\hline $\mathrm{R} \times \mathrm{L}$ & 2 & 0.062 & $1.23 \mathrm{~ns}$ & 2 & 0.003 & $0.05 \mathrm{~ns}$ \\
\hline Error & 57 & 0.048 & & 57 & 0.052 & \\
\hline \multicolumn{7}{|l|}{ E. arborea } \\
\hline $\mathrm{R}$ & 1 & 1.331 & $26.93 * * *$ & 1 & 1.438 & $49.66^{* * *}$ \\
\hline $\mathrm{L}$ & 2 & 0.087 & $1.75 \mathrm{~ns}$ & 2 & 0.594 & $20.52 * * *$ \\
\hline $\mathrm{R} \times \mathrm{L}$ & 2 & 0.091 & $1.83 \mathrm{~ns}$ & 2 & 0.151 & $5.20^{* *}$ \\
\hline Error & 57 & 0.049 & & 57 & 0.029 & \\
\hline
\end{tabular}

$* * *=\mathrm{p}<0.001, * *=\mathrm{p}<0.01, \mathrm{~ns}=$ not significant.

This behaviour was consistent for vegetative and reproductive parameters in all species except E. arborea. All differences between populations were significant except for relative foliar allocation in $C$. vulgaris and $E$. arborea, and relative flower allocation in $E$. arborea. Species more typical of acidic, aluminium-rich soils (i.e. E. australis and C. vulgaris according to Fig. 2) show a higher vegetative and reproductive (flower and fruit set) performance in the acidic site representing its supposed ecological optimum (A in Fig. 4). Erica scoparia presents its higher performance, both vegetative and reproductive, in the site representing its supposed ecological optimum, a cork-oak forest understorey on moderate acid soil with low aluminium and moderate tree cover (A in Fig. 4). On the contrary, E. arborea, with its optimum apparently in habitats with very dense tree cover (Fig. 3), shows a relatively higher foliar and flower allocation in such habitat (A in Fig. 4), although differences were not significant. However, its performance in terms of fruit set was just twice in the 'sub-optimum' site, an open garrigue on limestone (B in Fig. 4).

\section{Discussion}

The four heath species studied are known to thrive on acid and nutrient-poor soils and sunny exposures (Aubert 1977, 1978, Iason and Hester 1993, Rodríguez et al. 1994). Moreover, habit of the three Erica species is similar. However, a detailed analysis of their distribution and abundance in the Strait of Gibraltar region has revealed different ecological patterns along both soil aluminium and shade gradients. We suggest that the differences among these closely related species are mainly caused by their differential tolerance to limiting conditions (e.g. high aluminium, shading conditions) and the outcome of competition. Competition is difficult to detect from field descriptive data (Hastings 1987, Wilson and Gitay 1995) and its role in the structure of plant communities has been even questioned by some authors (e.g. Silvertown and Law 1987). However, the role of competition is expected to be relevant in the ecological distribution and coexistence of co-occurring congeneric species (Lamont et al. 1989, Mustart and Cowling 1993, Richardson et al. 1995, but see Sultan et al. 1998).

\section{Ecological response}

Edaphic requirements of E. scoparia and E. arborea are relatively broad (Aubert 1978, Rodríguez et al. 1994). Erica scoparia is perhaps more associated with sandy, acid soils than E. arborea (Aubert 1978, Ojeda et al. 1996a). Erica scoparia covers a broad range of habitats in Algeciras and it seems to be a strong competitor under relatively favourable edaphic conditions (Fig. 2), where it would exclude other heath species, although it does not show a significant preference in the edaphic (soil soluble aluminium) gradient (Table 3 ). Only under extreme edaphic conditions (i.e. high soluble aluminium) can E. australis and $C$. vulgaris take over. Erica arborea has a low abundance in Algeciras, except 
Fig. 3. Abundance of the four heath species in three situations on the shade (tree cover) gradient.
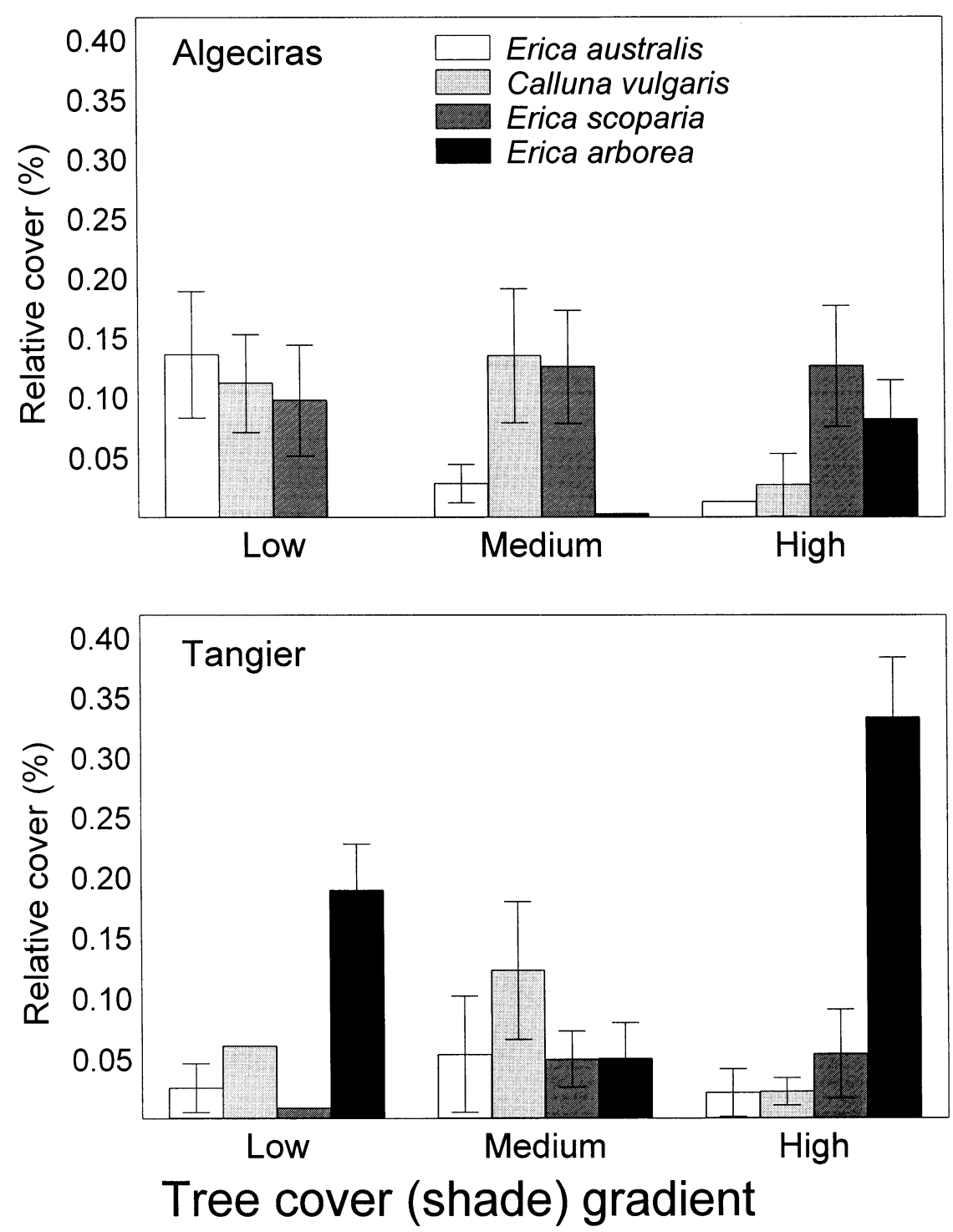

under very high tree cover (Fig. 3), where it can become the dominant species.

This pattern of ecological distribution is somewhat similar in Tangier, but appears blurred by the overwhelming presence of E. arborea throughout both environmental gradients (Figs 2 and 3). In contrast, abundance of E. scoparia seems to decrease significantly in Tangier compared to Algeciras.

Tilman (1988) presented a theoretical model under ideal conditions of limiting resources which predicts a higher competitive ability in plants that allocate more resources to production of photosynthetic tissue (i.e. vegetative performance). Reproductive performance is obviously more important for short-lived plants, especially annuals, but it should not be neglected in longer lived perennials.

Calluna vulgaris and E. australis showed a higher vegetative and reproductive performance on acidic soils, with high aluminium content and scarce tree cover (Fig. 4). In contrast, performance of E. scoparia,

Table 4. Matrix of ecological overlap between pairs of heath species in Algeciras and Tangier (in brackets)

\begin{tabular}{lllll}
\hline & E. australis & C. vulgaris & E. scoparia & E. arborea \\
\hline E. australis & & 0.48 & 0.17 & 0.01 \\
C. vulgaris & $(0.29)$ & $(0.36)$ & 0.42 & 0.05 \\
E. scoparia & $(0.21)$ & $(0.12)$ & $(0.14)$ & 0.16 \\
E. arborea & $(0.14)$ & & \\
\hline
\end{tabular}


both vegetative and reproductive, was higher under more mesic conditions (lesser acidic soils with low aluminium and higher tree cover). These three species showed higher performance values where they happened to be more abundant (i.e. 'optimum'), as expected. In contrast, E. arborea did not fit this trend. Although both relative foliar and flower allocation seemed to be higher under high tree cover, where this species is more abundant, differences were nonsignificant when compared with the other situation (i.e. garrigue-type shrubland on limestone, see Fig. 4) where $E$. arborea is much less abundant (Table 1). Furthermore, fruit set was significantly higher in the latter habitat (Fig. 4). However, caution must be taken when appealing to these results, owing to the paucity of data out of which they have been obtained (see Methods).

Despite $C$. vulgaris having a similar ecological response to $E$. australis and, in much lesser extent, to $E$. scoparia, it co-exists largely in Algeciras with these two species (Table 4), specially under low or null tree cover (Ojeda 1995, Ojeda et al. 1995). This capacity of coexistence is probably determined by their contrasted regeneration traits: the two Erica species are 'resprouter' (sensu Keeley 1986) whereas C. vulgaris does not resprout, but it is an effective seeder (Ojeda et al. 1996b). These differences in the 'regeneration niche' (cf. Grubb 1977) allow potentially competing species to coexist (Grubb 1977, Arroyo and Marañón 1990, Bond et al. 1992, Enright and Lamont 1992).

Erica arborea shows the largest size, in both belowand above-ground structures (Table 5). In the region, it can reach a tree-like habit, with trunk of $15 \mathrm{~cm}$ diameter and up to $6 \mathrm{~m}$ height, in preserved Quercus canariensis forests. In the Mediterranean, it is considered a competitive species in mesic and productive habitats, being a representative species of highly structured, low disturbed communities (de Benito 1948, Aubert 1977, Quezel 1981, Rivas Martínez 1987, Galán de Mera 1993, Paraskevopoulos et al. 1994). The pattern found in Algeciras, being only relatively abundant under high tree cover, also seems to feed this paradigm. However, how could we explain the overwhelming presence of $E$. arborea in Tangier throughout both environmental gradients?

\section{Geographical pattern: a hypothesis}

Since these four heath species are associated with acid, sandy soils (Aubert 1978, Rodríguez et al. 1994, Ojeda et al. 1996a), the smaller size and higher distance between sandstone patches in Tangier (Fig. 1, Ojeda et al. 1996a) would cause population isolation, making them vulnerable to local extinction (Bond et al. 1988). High disturbance regimes would probably increase adult plant mortality and hamper recruitment, amplifying the risk of extinction of isolated populations. Therefore, the 

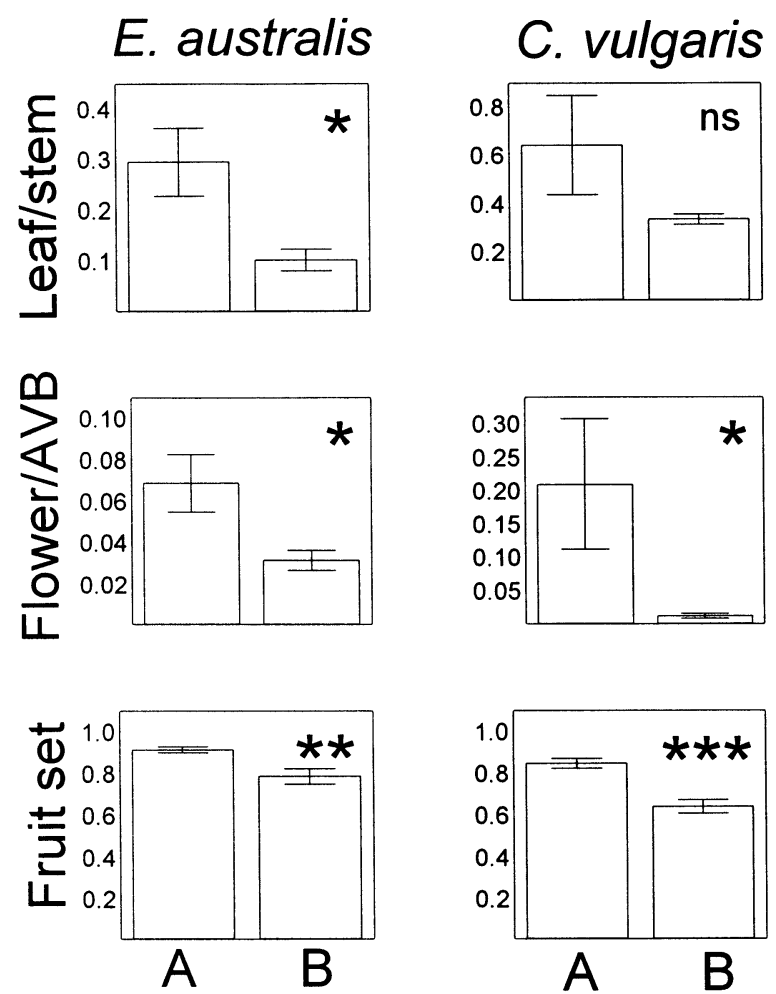


E. arborea

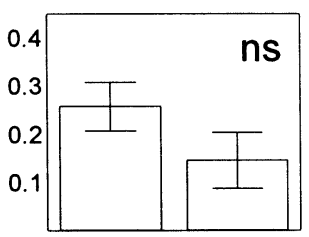

ns

Fig. 4. Performance of the four heath species in two contrasted ecological conditions, one close to the supposed optimum (A) and the other far from it (B). Performance has been estimated measuring three parameters: dry weight ratio of leaves and stems, dry weight ratio of flowers and above-ground vegetative biomass (AVB, i.e. leaves plus stems), and proportion of fruit set. Means \pm SD are shown based on three measurements per population, except in fruit set, where ten measurements per population were taken. $* * *=\mathrm{p}<0.001 ; * *=\mathrm{p}<0.01 ; *=\mathrm{p}<0.05$; ns, nonsignificant.

more fragmented arrangement of sandstone patches in Tangier and higher disturbance levels at this side of the Strait (Deil 1990, 1993, Ojeda 1995, Marañón et al. 1999) might account for the differences found between these otherwise similar peninsulas.

In Tangier, the three Erica species are under severe and recurrent slashing for household fuel and fencing (Ojeda 1995). Erica scoparia, mainly found on middle slopes (Ojeda et al. 1996a), would be under stronger pressure, as these sites are more likely to be near human settlements. Erica australis would escape from slashing in exposed ridges and higher parts of sandstone mountains, far from villages, where this species is still abundant. Although C. vulgaris is probably not slashed as heavily, owing to its smaller size, it would be affected by grazing at least in the same degree than the other species. Calluna vulgaris is seldom dominant in Tangier, but is found throughout the edaphic gradient in sandy, cleared areas.

But, considering the above argument, how can we explain the dominance of E. arborea in Tangier, especially in highly disturbed communities (Ojeda et al. 1996a)? The pattern found also contradicts the paradigm of considering E. arborea associated to highly structured, low disturbed communities. We suggest that E. arborea, in spite of being the more generalist of the four heath species (Aubert 1977, 1978, Rodríguez et al. 1994), (i) would be a weak competitor against E. scoparia and $E$. australis, but (ii) would be more resistant to disturbance, thus being favoured to some extent under recurrent slashing. This hypothesized higher resistance of $E$. arborea to recurrent slashing is testable and should indeed be tested experimentally. In fact, holocene pollen records in Tangier show peaks of abundance of $E$. arborea coinciding with historic periods of high disturbance (Reille 1977). In Algeciras, where disturbance is much less (Deil 1990, 1993, Ojeda 1995, Marañón et al. 1999), E. scoparia and E. australis would exclude E. arborea from most sites. Therefore, the association of E. arborea in Algeciras with high tree cover (in Quercus canariensis forest understoreys on deep soils) might be understood, not as a competitive success of this species under relatively favourable conditions, but as a restriction of this species to situations where the scarcity of light becomes limiting for other heath species.

Thus, tolerance to extreme conditions (e.g. high aluminium, shade) seems to explain the ecological distribution of E. australis, E. scoparia, E. arborea and C. vulgaris in the Strait of Gibraltar region. The more fragmented pattern of sandstone patches and the higher disturbance levels in Tangier might explain the differences in the patterns of ecological distribution of these four heath species between both peninsulas. 
Acknowledgements - We are grateful to Sergio, Marta, Mariángeles and Moli, who helped with field sampling and/or lab measurements. We specially thank Sergio Ruiz for the design of the linear sieve for separating heaths leaves and flowers. Javier Sánchez provided facilities to carry out the field work. This study was supported by the DGICYT (projects 91/894, 95/551 and APC-93/128) and DGES (project PB97/1177).

\section{References}

Anon. 1997. Statistica for Windows. - StatSoft, Tulsa.

Allen, S. E. (ed.) 1989. Chemical analysis of ecological materials. - Blackwell.

Arroyo, J. and Herrera, J. 1988. Polinización y arquitectura floral en Ericaceae de Andalucía Occidental. - Lagascalia 15 (extra): 615-623.

Arroyo, J. and Marañón, T. 1990. Community ecology and distributional spectra of Mediterranean shrublands and heathlands in southern Spain. - J. Biogeogr. 17: 163-176.

Aubert, G. 1977. Essai d'interprétation écologique de la répartition des Ericacées en Provence (région du Sud-est de la France). - Ecol. Mediterr. 3: 113-123.

Aubert, G. 1978. Relations entre le sol et cinq espèces d'ericacées dans le sud-est de la France. - Oecol. Plant. 13: 253-269.

Austin, M. P. 1985. Continuum concept, ordination methods and niche theory. - Annu. Rev. Ecol. Syst. 16: 39-61.

Benabid, A. 1982. Etudes phytoécologique, biogéographique, et dynamique des associations et séries sylvatiques du Rif Occidental (Maroc). - Ph.D. thesis, Univ. of Marseille, Marseille.

Bond, W. J., Cowling, R. M. and Richards, M. B. 1992. Competition and coexistence. - In: Cowling, R. M. (ed.), The ecology of fynbos. Nutrients, fire and diversity. Oxford Univ. Press, pp. 206-225

Bond, W. J., Midgley, J. J. and Vlok, J. 1988. When is an island not an island? Insular effects and their causes in fynbos shrublands. - Oecologia 77: 515-521.

CEBAC-CSIC 1963. Estudio agrobiológico de la provincia de Cádiz. - Diputación Provincial de Cádiz, Cádiz.

CSDIC 1983. Estudio sobre la Comarca del Campo de Gibraltar. - Diputación Provincial de Cádiz, Cádiz.

de Benito, N. 1948. Brezales y brezos. - Inst. For. Invest. Exp., Madrid.

Deil, U. 1990. Approches géobotaniques pour l'analyse des structures végétales anthropiques á travers des exemples marocains. - In: Bencherifa, A. and Pops, H. (eds), Le Maroc: space et société. Passau, Vol. spec. 1, pp. 157-165.

Deil, U. 1993. Le Tangerois: aspects biogéographiques et problèmes de conservation des ressources végétales. - In: Refass, M (ed.), Tanger. Espace, économie et societé. Univ. Mohammed V, Rabat, pp. 17-30.

El Hattab, A. 1989. La fôret, la biosphere et l'homme. - In: Anon. (ed.), Somade La fôret marocaine. Afrique Orient, Casablanca, pp. 117-127.

Enright, N. J. and Lamont, B. B. 1992. Recruitment variability in the resprouting shrub Banksia attenuata and nonsprouting congeners in the northern sandplain heaths of south western Australia. - Acta Oecologica 13: 727-741.

Galán de Mera, A. 1993. Flora y vegetación de los términos municipales de Alcalá de los Gazules y Medina Sidonia. Ph.D. thesis, Complutense Univ., Madrid.

Gimingham, C. H. 1960. Biological flora of the British Isles: Calluna vulgaris (L.) Hull. - J. Ecol. 48: 455-483.

Gimingham C. H. 1972. Ecology of heathlands. - Chapman and Hall.

Gimingham, C. H., Chapman, S. B. and Webb, N. R. 1979. European heathlands. - In: Specht, R. L. (ed.), Heathlands and related shrublands. Descriptive studies. Ecosystems of the World 9A. Elsevier, pp. 365-413.
Greuter, W., Burdet, H. M. and Long, G. (eds) 1986. MedChecklist, Vol. III. - OPTIMA, Berlin.

Groves, R. H. 1981. Heathland soils and their fertility status - In: Specht, R. L. (ed.), Heathlands and related shrublands. Analytical studies. Ecosystems of the World. 9B. Elsevier, pp. 143-150.

Grubb, P. J. 1977. The maintenance of species-richness in plant communities: the importance of the regeneration niche. - Biol. Rev. 52: 107-145.

Hastings, A. 1987. Can competition be detected using species co-occurrence data? - Ecology 68: 117-123.

Hobbs, R. J., Mallik, A. U. and Gimingham, C. H. 1984. Studies on fire in Scottish heathland communities. III. Vital attributes of the species. - J. Ecol. 72: 963-976.

Iason, G. R. and Hester, A. J. 1993. The response of heather (Calluna vulgaris) to shade and nutrients - predictions of the carbon-nutrient balance hypothesis. - J. Ecol. 81: $75-80$.

Ibarra, P. 1993. Naturaleza y hombre en el sur del Campo de Gibraltar: un análisis paisajístico integrado. - Junta de Andalucía, Sevilla.

INIA 1970. Mapas comarcales de suelos. Campo de Gibraltar (Cádiz). - Min. de Agricultura, Madrid.

Jahandiez, E. and Maire, R. 1931-34. Catalogue des plants du Maroc. - Minerva.

Keeley, J. E. 1986. Resilience of Mediterranean shrub communities to fires. - In: Dell, B., Hopkins, A. J. M. and Lamont, B. B. (eds), Resilience in Mediterranean-type Ecosystems. Junk Publ., pp. 95-112.

Lamont, B. B. 1982. Mechanisms for enhancing nutrient uptake in plants, with particular reference to mediterranean South Africa and Western Australia. - Bot. Rev. 48: $597-689$.

Lamont, B. B., Enright, N. J. and Bergl, S. M. 1989. Coexistence and competitive exclusion of Banksia hookeriana in the presence of congeneric seedlings along a topographical gradient. - Oikos 56: 39-42.

Marañón, T. et al. 1999. Biodiversity of woody species in oak woodlands of southern Spain and northern Morocco. For. Ecol. Manage. 115: 147-156.

Mustart, P. J. and Cowling, R. M. 1993. The role of regeneration stages in the distribution of edaphically restricted fynbos Proteaceae. - Ecology 74: 1490-1499.

Ojeda, F. 1995. Ecología, biogeografía y diversidad de los brezales del Estrecho de Gibraltar (sur de España y norte de Marruecos). - Ph.D. thesis, Univ. of Sevilla, Sevilla.

Ojeda, F. 1998. Distribución ecológica de los brezos (Erica australis, E. scoparia, E arborea y Calluna vulgaris) en la región del Estrecho de Gibraltar. - Almoraima 19: 285 290.

Ojeda, F., Arroyo, J. and Marañón, T. 1995. Biodiversity components and conservation of Mediterranean heathlands in Southern Spain. - Biol. Conserv. 72: 61-72.

Ojeda, F., Marañón, T. and Arroyo, J. 1996a. Patterns of ecological, chorological and taxonomic diversity on both sides of the Strait of Gibraltar. - J. Veg. Sci. 7: 63-72.

Ojeda, F., Marañón, T. and Arroyo, J. 1996b. Postfire regeneration of a mediterranean heathland in southern Spain. Int. J. Wildland Fire 6: 191-198.

Ojeda, F., Arroyo, J. and Marañón, T. 1998. The phytogeography of European and Mediterranean heath species (Ericoideae, Ericaceae): a quantitative analysis. - J. Biogeogr. 25: $165-178$

Oliver, E. G. H. 1989. The Ericoideae and the southern African heathers. - Bot. J. Linn. Soc. 101: 319-327.

Oliver, E. G. H. 1991. The ericoideae (Ericaceae) - a review. - Contrib. Bolus Herb. 13: 158-208.

Paraskevopoulos, S. P. et al. 1994. Plant growth strategies in evergreen-sclerophyllous shrublands (Maquis) in central Greece. - Vegetatio 115: 109-114.

Pearson, V. and Read, D. J. 1973. The biology of mycorrhiza in the Ericaceae II. The transport of carbon and phosphorus by the endophyte and the mycorrhiza. - New Phytol. 72: $1325-1331$. 
Quezel, P. 1981. Floristic composition and phytosociological structure of sclerophyllous matorral around the Mediterranean. - In: Di Castri, F., Goodall, D. W. and Specht, R. L. (eds), Mediterranean-type shrublands. Elsevier, pp. $107-121$.

Rebelo, A. G., Siegfried, W. R. and Oliver, E. G. H. 1985 Pollination syndromes of Erica species in the south-western Cape. - S. Afr. J. Bot. 51: 270-280.

Reille, M. 1977. Contribution pollenanalytique à l'histoire holocène de la végétation des montagnes du Rif (Maroc Septentrional). - Recherches francaises sur le Quaternaire. - Suppl. Bull. AFEQ 50: 53-76.

Richardson, D. M. et al. 1995. Coexistence of Banksia species in southwestern Australia: the role of regional and local processes. - J. Veg. Sci. 6: 329-342.

Rivas Martínez, S. 1987. Mapas y memoria de las series de Vegetación de España (1:400000). - Icona, Madrid.

Rodríguez, M., Ruiz, S. and Ojeda, F. 1994. Caracterización ecológica de tres especies del género Erica L. en las sierras del Aljibe y Campo de Gibraltar. - Almoraima 11: 215221.

Salvador, F. et al. 1996. Regeneración del brezal en el Campo de Gibraltar. - Almoraima 15: 145-154.

Sauvage, C. 1961. Recherches géobotaniques sur les subéraies marocaines. - Travaux de l'Inst. Sci. Chérifien. Série Bot. 21. Rabat.

Schoener, T. W. 1970. Non-synchronous spatial overlap of lizards in patchy habitats. - Ecology 51: 408-418.

Silvertown, J. and Law, R. 1987. Do plant need niches? Trends Ecol. Evol. 2: 24-26.
Sokal, R. R. and Rohlf, F. J. 1995. Biometry. 3rd ed. - W. H. Freeman.

Specht, R. L. and Moll, E. J. 1983. Mediterranean-type heathlands and sclerophyllous shrublands of the world: an overview. - In: Kruger, F. J., Mitchell, D. T. and Jarvis, J. U. M. (eds), Mediterranean-type ecosystems. The role of nutrients. Springer, pp. 41-65.

Sultan, S. E. et al. 1998. Contrasting ecological breadth of co-occurring annual Polygonum species. - J. Ecol. 86: $363-383$.

Tilman, D. 1988. Plant strategies and the dynamics and structure of plant communities. - Princeton Univ. Press.

Tomaselli, R. 1981. Main physiognomic types and geographic distribution of shrub systems related to mediterranean climates. - In: di Castri, F., Goodall, D. W., and Specht, R. L. (eds), Mediterranean-type shrublands. Elsevier, pp. 95-106.

Valdés, B. 1991. Andalucia and the Rif. Floristic links and a common Flora. - Bot. Chron. 10: 117-124.

Valdés, B., Talavera, S. and Galiano, E. F. (eds) 1987. Flora Vascular de Andalucía Occidental. - Ketres.

Wilson, J. B. and Gitay, H. 1995. Limitations to species coexistence: evidence for competition from field observations, using a patch model. - J. Veg. Sci. 6: 369-376.

Woolhouse, H. W. 1981. Soil acidity, aluminium toxicity and related problems in the nutrient environment of heathlands. - In: Specht, R. L. (ed.), Heathlands and related shrublands. Analytical studies. Ecosystems of the World. 9B. Elsevier, pp. 215-224. 